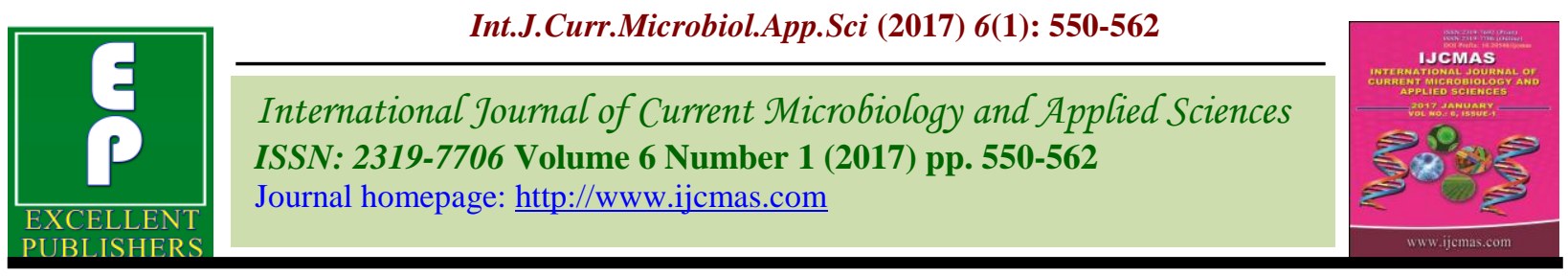

Original Research Article

http://dx.doi.org/10.20546/ijcmas.2017.601.068

\title{
Anti-inflammatory Effects of Chrysactinia mexicana Gray Extract in Growing Chicks (Gallus gallusdomesticus) Challenged with LPS and PHA
}

\author{
J.C. García-López ${ }^{1}$, G. Álvarez-Fuentes ${ }^{1}$, J.M. Pinos-Rodríguez ${ }^{2}$, Y. Jasso-Pineda ${ }^{1}$, \\ H.I. Contreras-Treviño ${ }^{1}$, M.A. Camacho-Escobar ${ }^{3}$, S. López-Aguirre ${ }^{1}$, \\ H.A. Lee-Rangel ${ }^{4}$ and J.A. Rendón-Huerta ${ }^{5}$
}

${ }^{1}$ Instituto de Investigación de Zonas Desérticas. Universidad Autónoma de San Luis Potosí. S.L.P. 78377. México

${ }^{2}$ Centro de Biociencias. Universidad Autónoma de San Luis Potosí. S. L. P. 78321. México

${ }^{3}$ Instituto de Industrias. Universidad del Mar Campus Puerto Escondido.

Puerto Escondido Oaxaca. 71980. México

${ }^{4}$ Faculatd de Agronomía y Veterinaria. Universidad Autónoma de San

Luis Potosí. S. L. P. 78321. México

${ }^{5}$ Coordinación Académica Región Altiplano Oeste.Universidad Autónoma de

San Luis Potosí.S.L.P. 78600. México

*Corresponding author

\section{A B S T R A C T}

\begin{tabular}{|l|}
\hline Key w or d s \\
$\begin{array}{l}\text { Chrysactinia } \\
\text { mexicana, } \\
\text { inflammation, } \\
\text { broiler. }\end{array}$ \\
\hline Article Info \\
\hline $\begin{array}{l}\text { Accepted: } \\
\text { 29 December } 2016 \\
\text { Available Online: } \\
\text { 10 January } 2017\end{array}$ \\
\hline
\end{tabular}

The effect of Chrysactinia mexicana extract on broilers challenged with LPS and PHA was evaluated. A two $2 \times 2$ factorial treatments examined effects of $C$. mexicana on broilers' immune response. 200 day old Cobb chicks were assigned to the following treatments: T1 control; T2 control plus LPS or PHA; T3 control plus $C$. mexicana; T4 control plus $C$. mexicana plus LPS or PHA. For the LPS challenge; nitrites concentration, leukocyte and erythrocyte count were measured. Phytohemagglutinin (PHA) was injected into the wing web and thickness and leukocyte populations were measured at 3, 6, 12,24 and 48 h.Weight gain, feed intake and feed conversion ratio was measured. The liver, bursa, thymus, and spleen were weighted. $\mathrm{T} 3$ had higher $(\mathrm{P}<0.05)$ average daily gain, total weight gain; lower $(\mathrm{P}<0.05)$ feed intake and feed conversion ratio. Treatment 3 and $\mathrm{T} 4$ had better-feed conversion ratio compared with $\mathrm{T} 1$ and $\mathrm{T} 2$. There were differences $(\mathrm{P}<0.05)$ for thymus, bursa and spleen weights among treatments, with higher $(\mathrm{P}<0.05)$ weights for LPS treatments. For the blood cells T2 had the highest $(\mathrm{P}<0.05)$ counts of leukocyte and erythrocytes. Treatment with LPS and without $C$. mexicana had higher levels of nitrites ( $\mathrm{P}>0.05)$. PHA increased wing web thickness at 3, 6, 12, 24 and $48 \mathrm{~h}$ post injection. The percentage of eosinophils in the wing web were smaller at 3,12,24 and $48 \mathrm{~h}$ post-PHA injection for treatment with $C$. mexicana. $C$. mexicana extract could be a possible alternative to antibiotic growth promoters in broilers.

\section{Introduction}

The use of antibiotics as growth promoters in broilers has provided an adequate intestinal integrity for a better digestion and absorption of nutrients. However, in the presence of low levels of antibiotic, resistant cells survive and grow, producing an antibiotic-resistant 
population. It is for this reason that consumers have concerns about the safety of poultry products in many countries (Bell, 2009). Consequently, the use of antibiotics for broilers has been limited worldwide. As a result alternatives are under research; herbs, spices, and various plant extracts have received attention as possible growth promoter replacements(Hernandez et al., 2004; Yang et al., 2009; Salianeh et al., 2011; Sadeghi et al., 2012; Pickler et al., 2013; Eyng et al., 2015).It has been shown that the incorporation of herbs and their associated essential oils into their diet may provide beneficial effects on poultry performance and health due to the antimicrobial activity of their phytochemical components (Lee et al., 2003). Chrysactinia mexicana Gray, commonly known as false Damiana is a small shrub distributed throughout the southwest United States and central and northern Mexico (Rzedowski and Rzedowski, 2001). The major chemical components of $C$. mexicana are eucalyptol (41.3\%), piperitone $(37.7 \%)$ and linalyl acetate $(9.1 \%)$ (Cardenas et al., 2005; Picard et al., 2016; Cuevas et al., 2016; Gang, 2013). Piperitone is a natural monoterpene ketone which is a component of some essential oils. Both stereoisomers, the D- form and the L-form, are known. The Dform has a peppermint-like aroma and has been isolated from the oils of plants from the genera Cymbopogon, Andropogon, and Mentha. Eucalyptol is a natural organic compound that is a colorless liquid. It is a cyclic ether and a monoterpenoid. Linalyl acetate is a naturally occurring phytochemical found in many flowers and spice plants (Gang, 2013). Cassani et al. (2015) demonstrated that $C$. mexicana aqueous extract induced an antidepressant effect in mice. Calzada et al. (2006) found that C.mexicana showed antiprotozoal activity against Entamoeba histolytica and Giardia lamblia, and also had an effect on Trichomonas vaginalis trophozoites (Calzada et al., 2007). Alanis et al. (2005) studied the in vitro antimicrobial effects of $C$. mexicana, which have demonstrated some bactericidal activity. Juarez et al. (2010) evaluated the effect of $C$. mexicanain maize weevil (Sitophilus Zeamays Motsch) and found that the leaf powder totally prevented F1 progeny from emerging. Cardenas et al. (2005) found that the essential oil of leaves of $C$. mexicana completely inhibited Aspergillus flavus growth. Moreover, Molina et al. (2007) found that $C$. mexicana showed the greatest antimicrobial activity against the drug resistant strain of Mycobacterium tuberculosis. Garcia et al. (2016a) tested the effect of $C$. mexicana ethanolic extract on laying hens challenged with Salmonella typhimurium, Colony forming units (CFU) were measured in laying hens organs (gizzard, ceca, crop and duodenum) and, hens receiving the $C$. mexicana extract had similar log CFU counts as the antibiotic treatment and, C.mexicana extract showed a bactericide effect. In addition, Garcia et al. (2016b) in a field study with laying hens with Salmonella infection in the backyard found a bactericide effect with the use of $C$. mexicana. The innate immune response is the first line of defense against pathogen exposure. Pathogen exposure induces transcription and translation of genes for cytokines and other immune mediators that promote inflammatory responses and induce acute-phase protein production (Zhang et al., 1995; Male et al., 2006; Abbas et al., 2008). The immune response to a wing-web injection of phytohemagglutinin (PHA) consists of a cutaneous basophil hypersensitivity $(\mathrm{CBH})$ response. This response primarily involves lymphocytes and basophils, which infiltrate in the first 2-6 h post challenge (lymphocytes) and 24-48 $\mathrm{h}$ post-challenge (basophils) (Koutsos et al., 2006; Koutsos et al., 2007; Silva et al., 2011). Nitric oxide (NO) is produced by macrophages through activation of the inducible enzyme nitric oxide synthase, 
which has powerful antiviral and anticancer properties (Stuehr and Nathan, 1989; Hussain and Qureshi, 1997; Alderton et al., 2001). Lypopolysaccharide (LPS) has been found to be a potent activator of immune and inflammatory cells, resulting in various proinflammatory cytokines (Dil and Qureshi, 2002). LPS challenge has been found to increaseNO secretion( $\mathrm{Li}$ et al. 2015).The objective of the present study was to evaluate the effect ofthe anti-inflammatory effects of C.mexicana Gray extract in growing chicks challenged with either LPS or PHA.

\section{Materials and Methods}

\section{Plant extract}

Plant collection was made from Guadalcazar village, located in a semi-desert area in the center zone of Mexico. Leaves were separated from the plants, placed on plates and dried for three weeks at room temperature. The leaves were then ground, and the extract was obtained by common extract methods, such as heat extraction, gravity column or percolation technique with ethanol. Two hundred $g$ of ground leaf powder samples were placed in a column by gravity or percolation and the solvent was added. This sat for $48 \mathrm{~h}$, using about $5 \mathrm{~L}$ of ethanolsolvent, the samples were then dried in an extraction chamber. The obtained extract was then concentrated at reduced pressure to $29^{\circ} \mathrm{C}$ with a rotavapor(R210/R-215 Buchi) (NCCLS, 2012; Pelczar and Reid,1958;Sidney et al., 1978). Finally, the extract was dried by the freeze drying process (cryodesicattion).

\section{In vivo}

Designs for the following experiments were similar, and exceptions are noted below. Two experiments were designed with a 2 x 2 factorial arrangement of treatments; experiment one consisted of two $C$. mexicana levels and two levels of LPS. $100 \mathrm{~d}$ old chicks (Cobb strain) were randomly assigned to one of 20 pens ( $n=5 /$ pen). At 14 d, chicks within pens were randomly assigned to one of two LPS treatments: chicks were either not injected (control) or were injected with $2 \mathrm{mg}$ LPS/kg body weight (BW) intra-abdominally. At six h post-LPS injection, four chicks/pen were bled via cardiac puncture into heparinized tubes for plasma isolation. The $C$. mexicana extract was administered orally via an esophageal cannula during 15 days at 20 $\mathrm{mg} / \mathrm{ml}$. Feed and water was offered ad libitum. Feed was formulated to meet or exceed the National Research Council (NRC, 1994) requirements for growing chicks (Table 1). All chicks were housed in identical brooder battery cages (Petersime Inc., Gettysburg, $\mathrm{OH}$ ) in a temperature controlled room $\left(25^{\circ} \mathrm{C}\right)$ under $24 \mathrm{~h}$ light. The dependent variables measured included: initial body weight, weight gain, final weight, feed intake and plasma NO at six $h$ post-LPS. The liver, bursa, thymus, and spleen were removed and weighted. In addition, leukocyte and erythrocyte counts were determined by Natt and Herrick's Stain method. Briefly, a standard red blood cell diluting pipette was used to dilute whole anticoagulated blood with the Natt\& Herrick's solution at the rate of 1:200. The diluted blood was allowed to mix for two minutes before it was discharged into the hemacytometer counting chamber. Then using the high dry (40X) objective of the microscope, the total number of red and white cells were counted (Campbell, 1995). The concentration of the NO metabolite was measured in plasma using the Griess reagent method. Nitrite assay. Nitrite levels were measured in 96-well microtiter plates by mixing $100 \mathrm{uL}$ of the macrophage culture supernatant with an equal volume of Griess reagent (one part $0.1 \%$ naphthylethylenediaminedihydrochloride to one part $1 \%$ sulfanilamide in 5\% phosphoric acid) as described by Hussain and Qureshi (1997). 
After 10 min incubation at room temperature, the change in color indicative of nitrite presence was quantified by reading the plates at A540 on an ELISA plate reader (Difco Laboratories, Inc., Detroit, MI 48232). An average of three measurements per sample was used in final analysis. A standard curve of optical densities (OD) at A540 was generated using various concentrations of sodium nitrate dissolved in RPMI-1640 growth medium (without phenol red). Nitrite levels of the culture supernatants were determined by comparing their OD values with that of the standard.

Experiment two consisted of two C. mexicana levels and two levels of PHA. $100 \mathrm{~d}$ old chicks (Cobb strain) were randomly assigned to one of 20 pens ( $\mathrm{n}=5 / \mathrm{pen})$. The $C$. mexicana extract was administered orally via an esophageal cannula over 15 days at $20 \mathrm{mg} / \mathrm{ml}$. Feed and water was offered ad libitum. Feed was formulated to meet or exceed the National Research Council (NRC,1994) requirements for growing chicks (Table 1). All chicks were housed in identical brooder battery cages (Petersime Inc., Gettysburg, $\mathrm{OH})$ in a temperature controlled room $\left(25^{\circ} \mathrm{C}\right)$ under $24 \mathrm{~h}$ light. At $14 \mathrm{~d}$ all birds were injected into the wing web with PHA (L8754, Sigma Aldrich, St. Louis, MO, USA; $100 \mu \mathrm{g}$ in $100 \mu 1 \mathrm{PBS})$. $\mathrm{CBH}$ response was examined by measuring wing web thickness in the injected wing and in the uninjected wing with low pressure digital calipers (model 573, Mitutoyo Inc., Kawasaki, Japan) at 3, 6, 12, 24 , and $48 \mathrm{~h}$ post-injection ( $\mathrm{n}=2 /$ pen*time period). CBH response was determined based upon the difference in the skin thickness between the injected and the uninjected wing. Tissue biopsies ( $\mathrm{n}=2 /$ pen*period time) were taken just after thickness measurements, using a dermal biopsy punch (3 $\mathrm{mm}$ biopsy punch, \#33-32, Miltex Inc., West Sacramento, CA, USA). Cell infiltration was quantified by microscopic evaluation of tissue sections
(Nikon Photo Shoot microscope). At least 100 leukocytes were counted at the site where the swelling was maximal, and leukocyte infiltration was most dense. Data are presented as the percentage of each cell type present within the tissue section.

\section{Data Analysis}

For the statistical analysis, a complete randomized design was used to assess the extract activity. Analysis of variance was performed with PROC GLM of SAS, and Tukey means with the statistical analysis system (SAS,1991) software program.

\section{Results and Discussion}

Performance parameters were affected by $C$. mexicana inclusion; $\mathrm{T} 3$ had higher $(\mathrm{P}<0.05)$ average daily gain, total weight gain; lower $(\mathrm{P}<0.05)$ feed intake and feed conversion ratio than the other treatments (Table 3). Treatment 3 and T4 that had C. mexicana inclusion had better feed conversion ratios compared with $\mathrm{T} 1$ and $\mathrm{T} 2$. In the case of thymus, bursa, and spleen weights there were differences $(\mathrm{P}<0.05)$ for treatments challenged with LPS showing higher $(\mathrm{P}<0.05)$ thymus, bursa and spleen weights than treatments without LPS challenge. For the blood cells; T2 had the highest $(\mathrm{P}<0.05)$ counts of leukocyte and erythrocytes in comparison with the other treatments (Table 2).

Plasma NO was increased by LPS treatment after six h post injection. Treatment injected with LPS and without $C$. mexicana had higher levels of nitrites $(\mathrm{P}<0.05)$ than treatment injected with $C$. mexicana (Figure 1). Nitrites concentration in the group without $C$. mexicana was almost two times higherthan the group with $C$. mexicana extract.

PHA injection increased wing web thickness at $3,6,12,24$ and $48 \mathrm{~h}$ postinjection. Figure 2 
shows that treatment with PHA and without C. mexicana extract had higher $(\mathrm{P}<0.05)$ values than treatment with PHA and with $C$. mexicana extract. Levels of inflammation remained high at 24 and $48 \mathrm{~h}$ in the treatment without $C$. mexicana. While the inflammation decreased $(\mathrm{P}<0.05)$ at 24 and $48 \mathrm{~h}$ with the $C$. mexicana extract (Figure 2).

The percentage of eosinophils in the wing web was affected by time $(\mathrm{P}<0.05)$ and was greatest at $12 \mathrm{~h}$ post-PHA for treatment C.mexicana + PHA $(\mathrm{P}<0.05)$ (Figure 3. A). Additionally a significant interaction $(\mathrm{P}<0.001)$ between PHA x $C$. mexicana $\mathrm{x}$ time demonstrates that chicks with $C$. mexicana and PHA challenge had lower percentage of eosinophils than treatment without $C$. mexicana at $3,12,24$ and $48 \mathrm{~h}$. Treatments without PHA challenge had lower $(\mathrm{P}<0.05)$ eosinophils percentage values than treatments challenged with PHA (Figure 3. A). The percentage of heterophils was affected by time $(\mathrm{P}<0.05)$ and was greatest at six $h$ post-PHA for treatment $-C$. mexicana + PHA $(\mathrm{P}<0.05)$ (Figure 3. B).Aftersix $h$ the percentage declined over time. Treatment + C. mexicana + PHA had reduced $(\mathrm{P}<0.05)$ heterophils percentage values at 12 and $24 \mathrm{~h}$. Treatments without PHA challenge had lower $(\mathrm{P}<0.05)$ heterophils percentage values than treatments challenged with PHA (Figure 3. B). The percentage of basophils was affected by time $(\mathrm{P}<0.05)$ and was greatest at $6 \mathrm{~h}$ postPHA for treatment $+C$. mexicana + PHA $(\mathrm{P}<0.05) \quad$ (Figure 3. C). An interaction between $C$. mexicana $\mathrm{x}$ time $(\mathrm{P}<0.001)$ demonstrates that chicks with $C$. mexicana had lower basophil percentage at $48 \mathrm{~h}$ post injection as compared to chicks without $C$. mexicana. Treatment $-C$. mexicana + PHA had reduced $(\mathrm{P}<0.05)$ basophils percentage values at $24 \mathrm{~h}$ post injection. Treatments without PHA challenge had lower $(\mathrm{P}<0.05)$ basophils percentage values than treatments challenged with PHA(Figure 3. C).
Performance parameters were affected by $C$. mexicana inclusion. Treatment Control $+C$. mexicana had higher average daily weight gain, total weight gain; and showed a better feed conversion ratio than the other treatments. These results agree with those found by Garcia et al. (2016b) in a study with Plymouth Rock Barred pullets using $C$. mexicana which found better average daily weight gain and a better feed conversion ratio. In the case of thymus, bursa and spleen weights there were significant differences for the treatments with LPS challenge, showing higher organ weights than treatments without LPS challenge. These results are in agreement with Koutsos et al. (2006) that found an increase in bursa, thymus, and spleen weights after an LPS injection in chickens. For the blood cells; treatment with PHA had the highest counts of leukocyte and erythrocytes in comparison with the other treatments. There are no previous studies about the effect of $C$. mexicana extract on the wing web inflammation induced with PHA or serum nitric oxide (NO) production induced by LPS. During the first two weeks of age, chicks are very sensitive to infections and mortality is high during this period. Therefore, feed additives that help to enhance the chicks' immune response are highly recommended. It has been reported that $C$. mexicana has some bactericide activity in laying hens and pullets challenged with Salmonella typhimurium (García et al., 2016ab). Nitric oxide (NO) is an important host defense effect or in innate immunity (Male et al., 2006; Abbas et al., 2008). It is generated by various tissues from L-arginine (Stuehr and Nathan, 1989). The increase of NO concentrations in this study induced by lipopolysaccharide (LPS) were suppressed significantly by $C$. mexicana extract. Li et al. (2009)found that dietary supplementation with chitosan (a natural alkaline polysaccharide) enhanced immune functions which were associated with the increase of NO secretion in the small intestine 
in broilers. Li et al. (2015) found that the increase of nitric oxide concentrations induced by LPS was reduced by chitosan in weaned piglets. It was reported that chitosan inhibits the production of NO in LPS activated RAW 264.7 cells, but stimulates the release of NO in resting or unstimulated peritoneal macrophages (Chou et al., 2003).

PHA injection increased wing web inflammation at 3, 6, 12, 24 and 48 h postinjection. Treatment with $C$. mexicana had lower inflammation values than treatment without C. mexicana. Silva et al. (2011) tested the effect of different levels on Vitamin $\mathrm{E}$ and found a lasting cell mediated response with $65 \mathrm{mg} / \mathrm{kg}$ when chickens were challenged with PHA. Koutsos et al. (2007) studied the effect of lutein on cutaneous basophil response in chickens and found cell reactions up to $48 \mathrm{~h}$ post PHA-injection. The percentage of eosinophils, heterophils and basophils in the wing web was affected by time and, in general, treatment with $C$. mexicana showed less percentages than treatments without $C$. mexicana in chicks challenged with PHA.

Table.1 Basal diet composition1

\begin{tabular}{|l|l|}
\hline Ingredient & $\mathrm{g} / \mathrm{kg}$ diet \\
\hline Yellow corn $8 \%$ & 541.8 \\
\hline Soybean meal 46.5\% & 369.5 \\
\hline Calcium carbonate 38\% & 5.6 \\
\hline Cornstarch & 20.0 \\
\hline Vegetable oil & 30.2 \\
\hline Dicalcium phosphate & 17.5 \\
\hline Sodium chloride & 5.0 \\
\hline Vitamin mix ${ }^{2}$ & 2.5 \\
\hline Mineral mix & 2.5 \\
\hline DL-Methionine & 3.5 \\
\hline Threonine & 0.5 \\
\hline L-Lysine & 0.4 \\
\hline Choline & 1.0 \\
\hline Chemical composition & \\
\hline Metabolisable energy, Kcal/kg & 2954 \\
\hline Crude protein, \% & 23.91 \\
\hline Calcium, \% & 0.42 \\
\hline Phosphorus, \% & 0.55 \\
\hline Methionine, \% & 0.64 \\
\hline Lysine, \% $\%$ & 1.27 \\
\hline Threonine, \% & 0.88 \\
\hline
\end{tabular}

${ }^{1}$ Diet was offered ad libitum for the duration of the trial, and was formulated to meet or exceed all requirements for growing chickens (NRC,1994).

\footnotetext{
${ }^{2}$ Vitamin mix provided (per kg final diet): thiamin, $1.8 \mathrm{mg}$; riboflavin, $3.6 \mathrm{mg}$; pantothenic acid, $11.5 \mathrm{mg}$; niacin, 35 $\mathrm{mg}$; pyridoxine, $3.5 \mathrm{~g}$; folic acid, $0.6 \mathrm{mg}$; biotin, $0.2 \mathrm{mg}$; vitamin B- $12,10 \mu \mathrm{g}$; retinylpalmitate, $0.9 \mathrm{mg}$; cholecalciferol, $50 \mu \mathrm{g}$, all-rac- $\alpha$-tocopheryl acetate, $36.8 \mathrm{mg}$; menaquinone, $5 \mathrm{mg}$. Mineral mix provided (per $\mathrm{kg}$ final diet) selenium, $0.2 \mathrm{mg}$; copper, $8.1 \mathrm{mg}$; zinc, $40.7 \mathrm{mg}$; manganese, $62 \mathrm{mg}$; iron, $105.4 \mathrm{mg}$; iodine, $0.35 \mathrm{mg}$.
} 
Table.2 Means of broiler performance, organ weights and blood cells with different treatments

\begin{tabular}{l|ccccc}
\hline Treatment & $\mathrm{T} 1$ & $\mathrm{~T} 2$ & $\mathrm{~T} 3$ & $\mathrm{~T} 4$ & SEM \\
\hline Performance & & & & & \\
Initial body weight [g] & 40.95 & 42.17 & 41.05 & 41.36 & 0.048 \\
Final bodyweight [g] & $449.05^{\mathrm{b}}$ & $439.92^{\mathrm{b}}$ & $501.75^{\mathrm{a}}$ & $453.98^{\mathrm{b}}$ & 2.145 \\
Total weight gain [g] & $408.10^{\mathrm{b}}$ & $397.75^{\mathrm{b}}$ & $460.70^{\mathrm{a}}$ & $412.62^{\mathrm{b}}$ & 4.135 \\
Average daily gain [g] & $29.15^{\mathrm{b}}$ & $28.41^{\mathrm{b}}$ & $32.90^{\mathrm{a}}$ & $29.47^{\mathrm{b}}$ & 0.211 \\
Feed intake [g] & 496.23 & 494.45 & 492.78 & 489.21 & 5.210 \\
Feed Conversion Ratio & $1.21^{\mathrm{b}}$ & $1.24^{\mathrm{b}}$ & $1.06^{\mathrm{a}}$ & $1.18^{\mathrm{b}}$ & 0.012 \\
& & & & & \\
Organ weights & & & & & \\
& & & & & \\
Thymus[g] & $0.829^{\mathrm{b}}$ & $0.878^{\mathrm{a}}$ & $0.833^{\mathrm{b}}$ & $0.861^{\mathrm{a}}$ & 0.024 \\
Bursa [g] & $0.918^{\mathrm{b}}$ & $0.976^{\mathrm{a}}$ & $0.922^{\mathrm{b}}$ & $0.991^{\mathrm{a}}$ & 0.034 \\
Spleen [g] & $0.301^{\mathrm{b}}$ & $0.372^{\mathrm{a}}$ & $0.314^{\mathrm{b}}$ & $0.368^{\mathrm{a}}$ & 0.019 \\
& & & & & \\
Blood Cells & & & & & \\
& & & & & \\
Leukocyte/ mm3 & $1.78^{\mathrm{b}}$ & $2.74^{\mathrm{a}}$ & $1.80^{\mathrm{b}}$ & $1.85^{\mathrm{b}}$ & 0.011 \\
Erythrocytes/mm3 & $26.12^{\mathrm{b}}$ & $45.91^{\mathrm{a}}$ & $27.52^{\mathrm{b}}$ & $28.27^{\mathrm{b}}$ & 3.221 \\
& & & & & \\
\hline
\end{tabular}

a,b,c,d Means within columns with different letter are significant different $(\mathrm{P}<0.05)$. T1=Control basal diet; $\mathrm{T} 2=$ Control $+\mathrm{LPS}$ or PHA, T3=Control + C. mexicana $; 4=$ control + C. mexicana + LPS or PHA.

Fig.1 Means of nitrites concentration of chick serum of different treatments

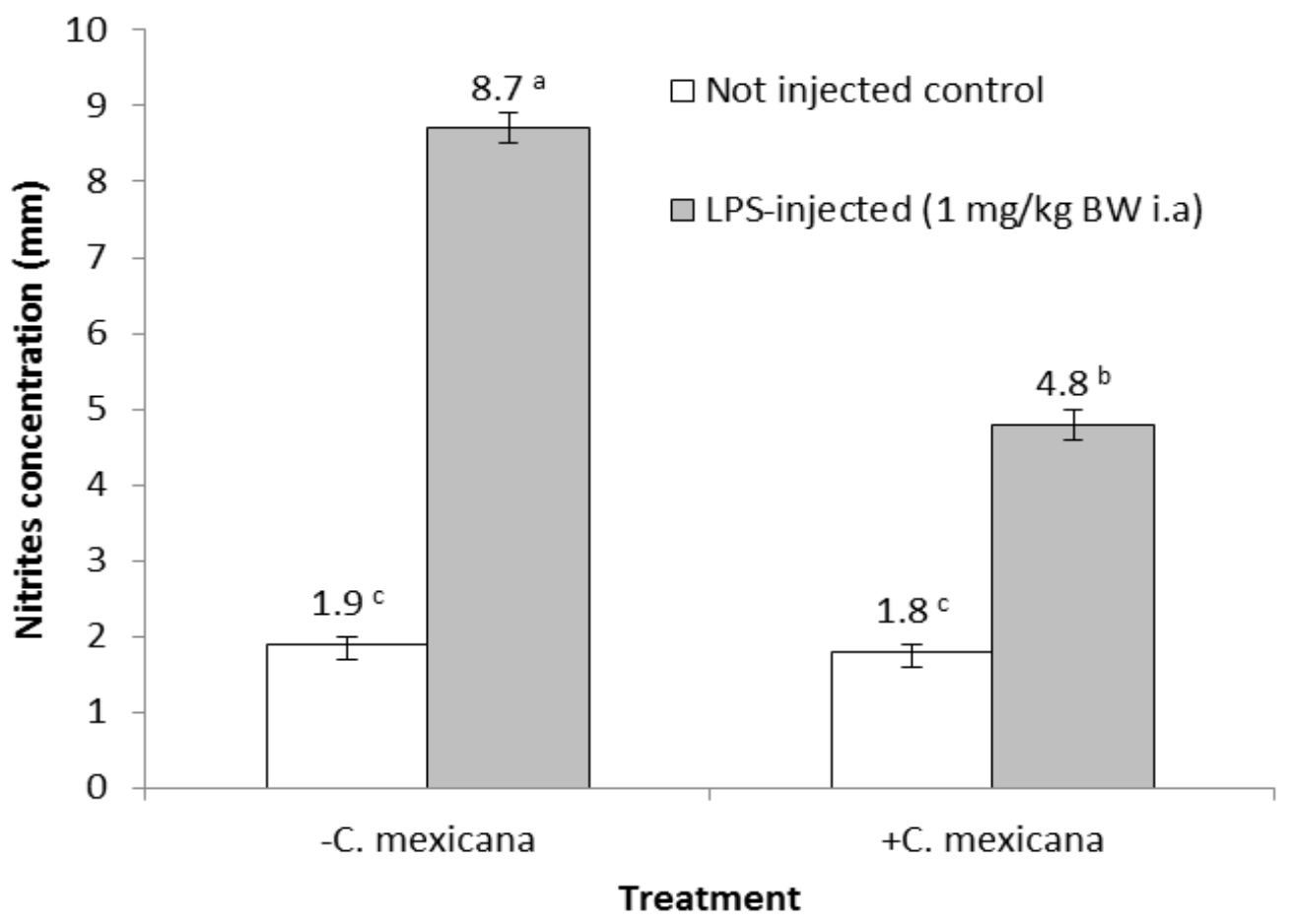


Fig.2 Means of inflammation (mm) in the wing-web at different time after PHA injection

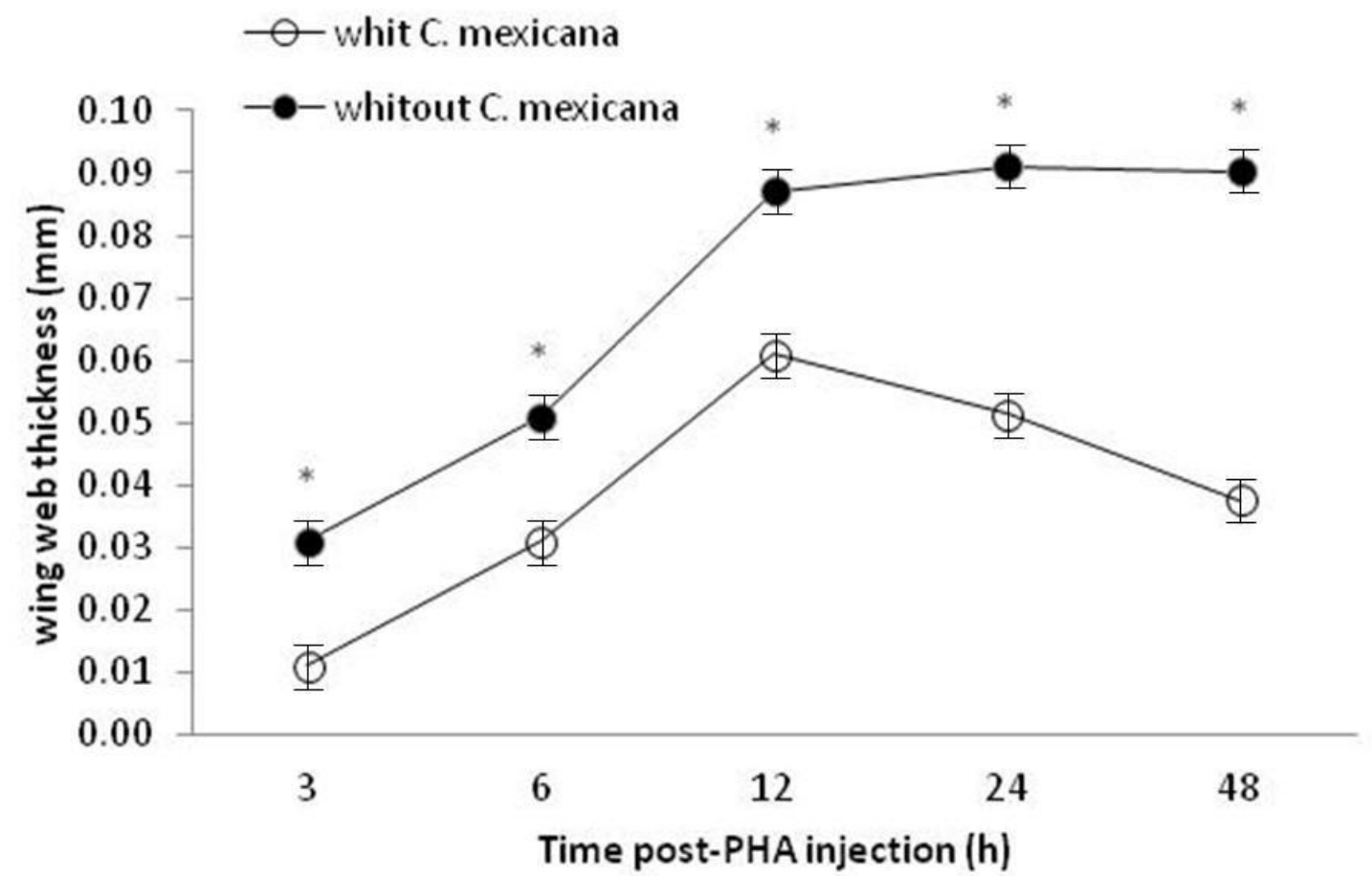

Fig.3 Effect of PHA injection on leukocyte populations in the wing web of chickens with C. mexicana and without $C$. mexicana. A. Eosinophils percentages. B. Heterophils percentage.

C Basophils percentage

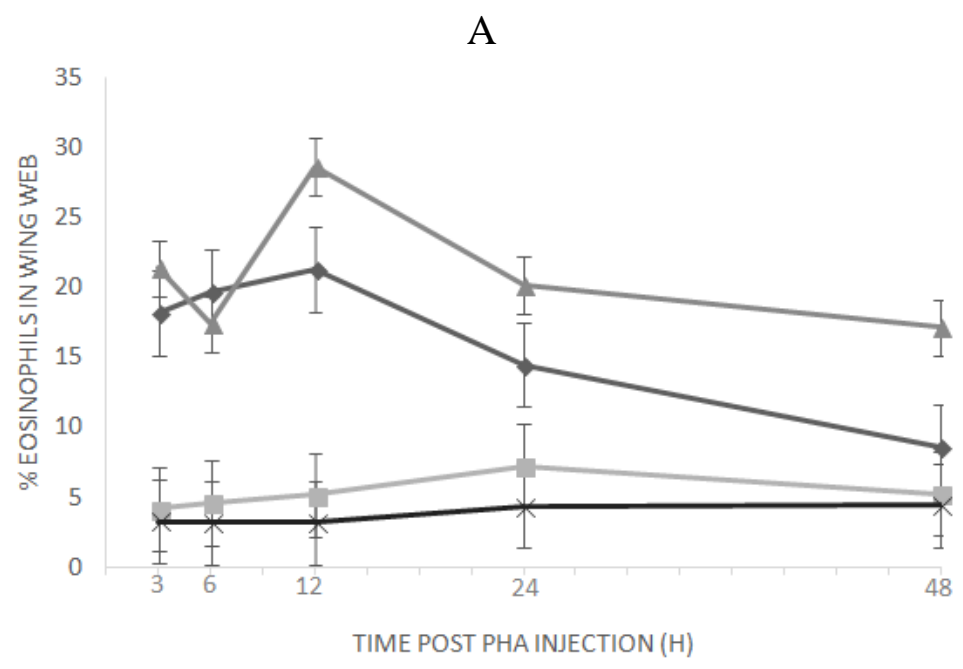


B

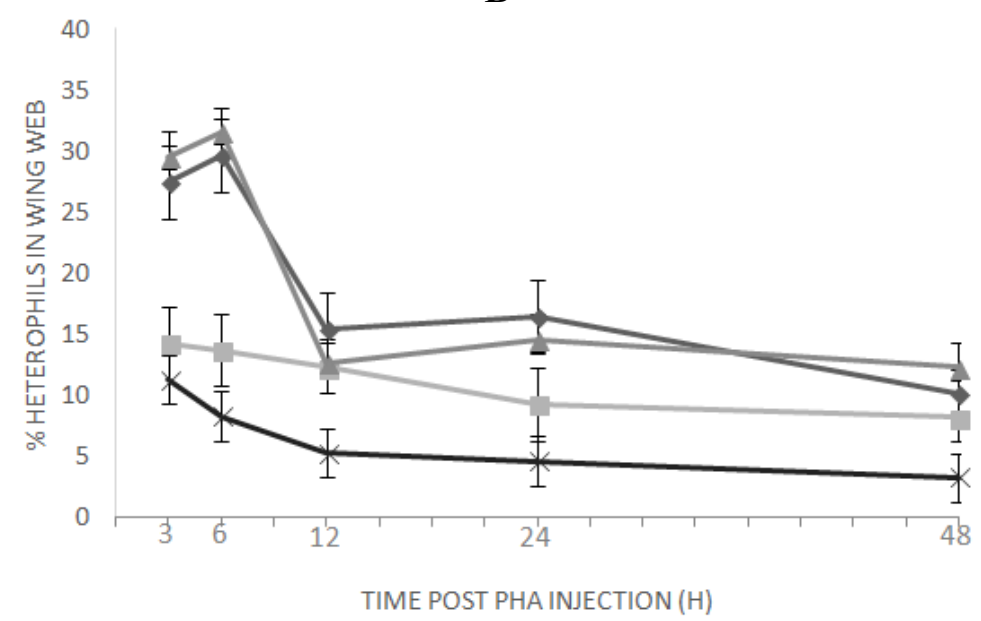

$\mathrm{C}$

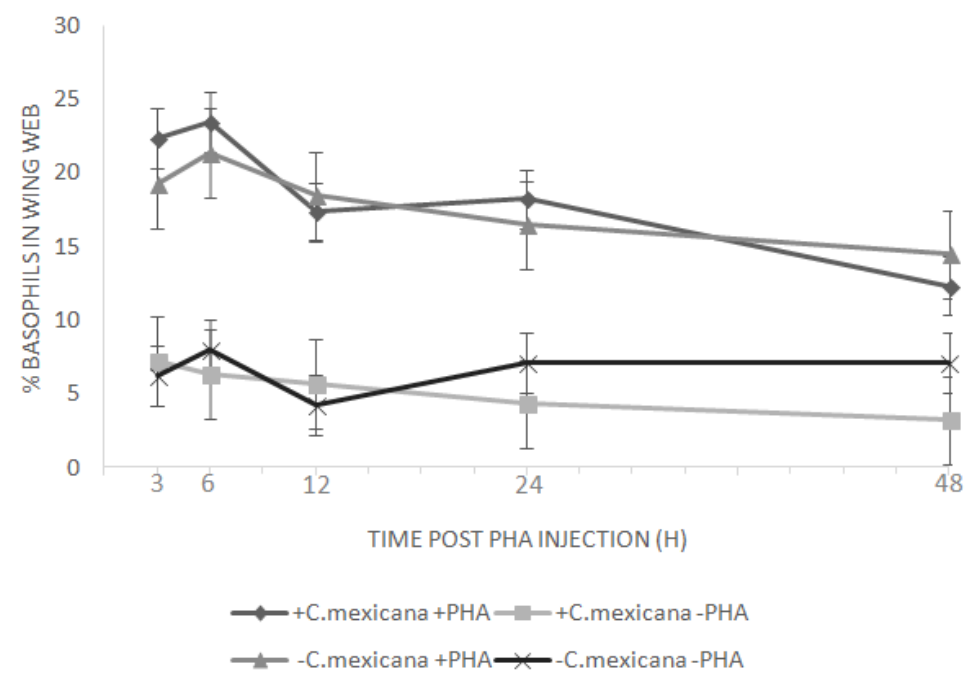

Treatments without PHA challenge had lower leukocyte percentages values than treatments challenged with PHA. Koutsos et al., (2007) measured cell infiltration testing different levels of lutein and found that basophil infiltration was greater for chicks fed $0 \mathrm{mg}$ of lutein after a PHA challenge. Although the $C$. mexicana extract mechanism of action is not clear, C. mexicana may contribute macrophages to produce less $\mathrm{NO}$, helping the chicks immune system to counteract the PHA inflammation.Some of the research findings for $C$. mexicana that may contribute to enhance immunity were performed by Molina et al. (2007) that tested three different extracts of $C$. mexicana (aqueous, methanol and diethyl ether) and found a bactericide effect with two strains of Mycobacterium tuberculosis. Moreover, Cantrell et al. (1998) reported $C$. mexicana to have antimycobacterial activity. In another experiment, Delgado and Rios (1991) performed a phytochemical analysis and monoterpenes were identified. Another experiment with essential oil from leaves showed some antifungal activity (Cardenas $e t$ al., 2005). The pharmacological effect of $C$. mexicana could be related to intracellular concentration regulation of $\mathrm{Ca}^{++}$(Park et al., 2011). The action mechanism of a majority of C. mexicana components has been reported as eucalyptol inhibited contractions induced by 
carbachol (Shah et al., 2011;Mangprayool et al., 2013). It also has anti-diarrheic activity (Yvon et al., 2012). Eucalyptol and 26 other diterpenes have been reported to decrease cytokines IL-2 (Th1) and IL-10 (Th2) that are anti-inflammatory inhibiting the response of $\mathrm{T}$ cells ( $\mathrm{Ku}$ and Lin, 2013). Finally, it has been reported that the essential oil from Cymbopogon proximus contains piperitone as the highest compound (73.8\%). This compound antagonizes the actions of serotonin and histamine, by interaction of its receptors (Al-Taweel et al.,2013). All the above experiments showed that $C$. mexicana might enhance the immune response in growing chicks. According to the results of this experiment, the use of $C$. mexicana extract could be a good alternative for antibiotic growth promoters in broilers.

In conclusion the Chrysactinia mexicana extract showed good performance traits. The use of the extract decreased the NO secreted levels and had a lower cell infiltration in chicks challenged with LPS and PHA. More studies are warranted to elucidate the mechanism of action of the $C$. mexicana extract.

\section{Acknowledgements}

This study was supported by the research support fund of the UASLP CO7-FAI04.22.24

And the Prodep Grant 103.5/08/5636

\section{References}

Alderton, W.K., C.E. Cooper, and Knowles, R.G. 2001. Nitric oxide synthases. Structure, function and inhibition. Biochemical J., 357: 593-615.

Abbas, A.K., A.H. Lichtman, and Pillai, S. 2008. Cellular and molecular immunology. Sixth ed. Elsevier Saunders. 566p.
Alanis, A.D., F. Calzada, J.A. Cervantes, J. Torres, and Ceballos,G.M. 2005. Antibacterial properties of some plants used in Mexican traditional medicine for the treatment of gastrointestinal disorders. J. Ethnopharmacol., 100:153157.

Al-Taweel A., G. Fawzy, S. Perveenand Tahir El,K.2013. Gas Chromatographic Mass Analysis and Further Pharmacological Actions of Cymbopogon proximus Essential Oil. Drug res., 63(9): 484 488.

Bell, J.G. 2009. Factors limiting production efficiency and profitability from smallholder poultry production. World's Poultry Sci. J., 65: 207-210.

Calzada, F., M.L. Yepez, and Tapia,C.A. 2007. Effect of Mexican medicinal plant used to treat trichomoniasis on Trichomonas vaginalis trophozoites. J. Ethnopharmacol., 113: 248-251.

Calzada, F., M.L. Yepez, and Aguilar,A. 2006. In vitro susceptibility of Entamoeba histolytica and Giardia lamblia. J. Ethno-pharmacol., 108: 367370.

Cárdenas, O.N.C., S.M.A. Zavala, R.J.R. Aguirre, G.C. Pérez, and Pérez,G.S. 2005. Chemical composition and antifungal activity of essential oil of Chrysactinia Mexicana Gray. J. Agric. Food Chem., 53: 4347-4349.

Cassani, J., C.O.A. Ferreyra, B.A.M. Dorantes, V.R.M. Vigueras, B.D. Arrieta, and Estrada, R.R. 2015. Antidepressant-like and toxilogical effects of standardized aqueous extract of Chrysactinia mexicana A. Gray (Asteraceae) in mice. $J$. ethnopharmacol., 171: 295-306.

Cantrell, C.L., N.H. Fischer, L. Urbastsch, M.S. McGuire, and Franzblau, S.G. 1998. Antimycobacterial crude plant extracts from South, Central and North America. Phytomed., 5: 137-145. 
Chou, T.C., E. Fu, and Shen, E.C. 2003. Chitosan inhibits prostaglandin E2 formation and cyclooxygenase-2 induction in lipopolysaccharide-treated RAW 264.7 macrophages. Biochemical and Biophysical Res. Communications, 308: 403-407.

Cuevas, F.J., R.J.M. Moreno, F. Arroyo, A. Daza, and Ruiz, M.M.J. 2016. Effect of management (organic vs conventional) on volatile profiles of six plum cultivars (Prunus salicina Lindl.). A chemometric approach for varietal classification and determination of potential markers. Food Chemistry, 2(4):05-15.

Delgado, G., and Rios,M.Y.1991. Monoterpens from Chrysactinia mexicana. Phytochem., 30(3): 31293131.

Dil, N., and Qureshi, M.A. 2002. Involvement of LPS related receptors and nuclear factor Kappa-B in differential expression of inducible nitric oxide synthase in chicken macrophages from different genetic backgrounds. Veterinary Inmmunol. Immunopathol., 88: 149-161.

Eyng, C., A.E.Murakami, I.C.O. Rojas, R.B. Pedroso, T.G.U. Silveira, and Lourenzo, D.A.L. 2015. Effect of diet inclusion of ethanolic extract of propolis on broiler immunity. Archivos Medicos Veterinarios, 47: 185-192.

Gang, D. 2013. 50 years of phytochemistry research. Ed. Springer. Vol.43

García, L.J.C., J.M.R. Pinos, G.F. Álvarez, B.I.F. Juárez, Y.P. Jasso, M.A.E. Camacho, S.A. López,Hernández,L.O.A. 2016b. Effect of Chrysactinia mexicana Gray extract on laying hens organs challenged with Salmonella typhimurium. J. Appl. Life Sci. Int., 5(1):1-8.

García, L.J.C., F.G. Álvarez, R.J.M. Pinos, P.Y.Jasso, P.E. Zapata, R.H.A. Lee,
A.S. Lopez, and Camacho, E.M.A. 2016a. Effect of a plant extract in several traits of Plymouth Rock Barred hens and pullets challenged with Salmonella typhimurium in a rural village in Central Mexico. Animal Rev., 3(2):43-51.

Hernandez, F., J. Madrid, V. Garcia, J. Orengo, and Mejias, M.D. 2004. Influence of two plant extracts on broiler performance, digestibility and digestive organ size. Poultry Sci., 83:169-174.

Hussain, I., and Qureshi, M.A. 1997. Nitric oxide synthase activity and mRNA expression in chicken macrophages. Poultry Sci., 76:1524-1530.

Juárez, F.B.I., P.Y. Jasso, R.J.R. Aguirre, and Jasso,P.I. 2010. Effect of Astereacea powder on maize weevil, Sitophilus zeamais Motsch. Polibotánica, 30:123125.

Johnson, R.W. 1998. Immune and endocrine regulation of food intake in sick animals. Domestic Animal Endocrinol., 15:309-319.

$\mathrm{Ku}, \mathrm{C}$. and Lin, J. 2013. Anti-inflammatory effects of 27 selected terpenoid compounds tested through modulating Th1/Th2 cytokine secretion profiles using murine primary splenocytes. Food Chem., 141(2):1104-1113.

Koutsos, E.A., L.J.C. García, and Klasing, K.C. 2006 Carotenoids from in ovo or dietary sources blunt systemic indices of the inflammatory response in growing chicks (Gallus gallus domesticus). J. Nutri., 136, 1027-1031.

Koutsos, E. A., L.J.C. García, and Klasing, K.C. 2007. Maternal and dietary carotenoids interactively affect cutaneous basophil responses in growing chickens (Gallus gallusdomesticus). Comparative Biochemistry and Physiol., Part B. 147:87-92. 
Lee, K.W., H. Everts, H.J. Kappert, M. Frehner, R. Losa, and Beynen, A.C. 2003.Effects of dietary essential oil components on growth performance, digestive enzymes and lipid metabolism in female broiler chickens. British Poultry Sci, 44:450-457.

Li, J., B. Shi, S. Yan, L. Jin, Y. Guo, and Li,T. 2015. Effects of chitosan on nitric oxide production and inducible nitric oxide synthase activity and mRNA expression in weaned piglets. Czech $J$. Anim. Sci. 60(8): 359-366.

Li, H.Y., S. Yan, B. Shi, and Guo, X. 2009. Effect of chitosan on nitric oxide content and inducible nitric oxide synthase activity in serum and expression of inducible nitric oxide synthase mRNA in small intestine of broiler chickens. Asian-Australasian J. Animal Sci., 22:1048-1053.

Male, D., J. Brostoff, D.B., Roth, and Roitt, I. 2006. Immunology. Seventh ed. Mosby Elsevier. $552 \mathrm{p}$.

Mangprayool, T., S. Kupittayanant,and Chudapongse, N. 2013. Participation of citral in the bronchodilatory effect of ginger oil and possible mechanism of action. Fitoterapia, 17(89C): 68-73.

Molina, S.G.M., L.A. Perez, M.P. Becerril, A.R. Salazar, F.S. Said, and Waksman, T.N. 2007. Evaluation of the flora of Northern Mexico for in vitro antimicrobial and antituberculosis activity. J. Ethnopharmacol., 109: 435441.

NCCLS/CLSI - National Committee for Clinical Laboratory Standards. 2012. Methods for Dilution Antimicrobial Susceptibility Tests for Bacteria That Grow Aerobically; Approved Standard. Ninth Edition. Document M07-A9. 32 (2): $68 \mathrm{p}$.

NRC. 1994. Nutrient requirements of poultry. $8^{\text {th }}$ Rev. Ed. National Academy Press. Washington, D.C. 157p.
Park, Y., D.Baek, W. Kim, J. Kim, S. Yang, S. Jung, B. Jang, C. Choi, D. Han, Y. Kim, Y. Chung, and Kim, S. 2011. Clinical characteristics of microscopic colitis in Korea: Prospective multicenter study by KASID. Gut and Liver, 5 (2):181-186.

Pelczar, J.M. and Reid, D.R. 1958. Microbiol., McGraw-Hill. Book Company, Inc. New York, Toronto, London. 457p.

Picard, M., G, Lytra, S. Tempere, J.C. Barbe, G. Revel, and Marchand, S. 2016. Identification of Piperitone as an Aroma Compound Contributing to the Positive Mint Nuances Perceived in Aged Red Bordeaux Wines. J. Agri. Food Chem., 1(3): 01-20.

Pickler, L., B.C. Beirao, R.M. Hayashi, J.F. Duran, M.C. Lourenco, L.F. Caron, and Santin,E. 2013. Effect of sanguinarine in drinking water on Salmonella control and the expression of immune cells in peripheral blood and intestinal mucosa of broilers. J. Appl. Poultry Res., 22: 430-438.

Rzedowski, J. andRzedowski, C.G. 2001. Flora fanerogámica del valle de México, $2^{a}$ edición, Instituto de Ecología A.C. y Comisión Nacional para el Conocimiento y Uso de la Biodiversidad: Pátzcuaro, Michoacán, México, p. 17.

Sadeghi, G.H., A. Karimi, J.S.H. Padidar, T. Azizi, and Daneshmand, A. 2012. Effects of cinnamon, thyme and turmeric infusions on the performance and immune response in of 1 to 21 day old broilers. Brazilian J. Poultry Sci., 14(1): 15-20.

Salianeh, N., M.R. Shirzad, and Seifi, S. 2011. Performance and antibody response of broiler chickens fed diets containing probiotic and prebiotic. $J$. Appl. Animal Res., 39(1):65-67.

Silva, I.C.M., A.M.L.Ribeiro, C.W.Canal, 
M.M.Vieira, C.C.Pinheiro, T. Goncalves, M.L. Moras, and Ledur,V.S. 2011. Effect of vitamin $E$ levels on the cell mediated immunity of broilers vaccinated against coccidiosis. Brazilian J. Poultry Sci., 13(1): 53-56.

SAS Institute. 1991. SAS User's Guide: Statistics. SAS Institute Inc., Cary, NC. $1028 \mathrm{p}$.

Stuehr, D.J., and Nathan,C.F. 1989. Nitric oxide. A macrophage product responsible for cystitis and respiratory inhibition in tumor target cells. $J$. Experimental Med., 169:1543-1555.

Sidney, M.F., J.M. William, and Elvyn, G.S. 1978. Bailey and Scott's Diagnostic Microbiology. C.V. Mosby Company, 5 th ed. St. Louis MO. 514 p.

Shah, A., A. Gilani, K. Abbas, M. Rasheed, A. Ahmed, and Ahmad,V. 2011. Studies on the chemical composition and possible mechanisms underlying the antispasmodic and bronchodilatory activities of the essential oil of Artemisia maritimal. Archives of Pharmacol Res., 34(8):1227-1238.

Yang, Y., P.A. Iji, and Choct,M.. 2009. Dietary modulation of gut microflora in broiler chickens: a review of the role of six kinds of alternatives to in-feed antibiotics. World's Poultry Science J., 65: 97-114.

Yvon, Y., E. Raoelison, R. Razafindrazaka, A. Randriantsoa, M. Romdhane, N. Chabir, M. Mkaddem and Bouajila, J. 2012. Relation between chemical composition or antioxidant activity and antihypertensive activity for six essential oils. J. Food Sci., 77(8):H184H191.

Zhang, S., H.S. Lillehoj, and Ruff, M.D. 1995. Chicken tumor necrosis like factor I. in vitro production by macrophages stimulated with Eimeriatenella or bacterial LPS. Poultry Sci., 74: 1304-1310.

\section{How to cite this article:}

García-López, J.C., G. Álvarez-Fuentes, J.M. Pinos-Rodríguez, Y. Jasso-Pineda, H.I. Contreras-Treviño, M.A. Camacho-Escobar, S. López-Aguirre, H.A. Lee-Rangel and RendónHuerta, J.A. 2017. Anti-inflammatory Effects of Chrysactinia mexicana Gray Extract in Growing Chicks (Gallus gallusdomesticus) Challenged with LPS and PHA. Int.J.Curr.Microbiol.App.Sci. 6(1): 550-562. doi: http://dx.doi.org/10.20546/ijcmas.2017.601.068 